\title{
Cultural value as the basis for the microfinance development of the Farmer's Group Association
}

\author{
Nilai budaya sebagai dasar pengembangan keuangan mikro Gabungan \\ Kelompok Tani
}

\author{
Bernard Edheney Huruta \& Yulius Pratomo \\ Department of Economics, Faculty of Economics and Business, Universitas Kristen Satya Wacana \\ Address: Jalan Diponegoro No 52-60, Salatiga, Central Java 50711 \\ E-mail: 222014019@student.uksw.edu \& yulius.pratomo@staff.uksw.edu
}

\begin{abstract}
This study aims to describe the form of local wisdom (cultural value) in rural microfinance - this study conducted from October until December 2018 in Wangga Village, East Sumba. A qualitative method was used to picture the phenomenon of local wisdom-based microfinance development in communities. The authors used in-depth interviews with eight informants from the Rinjung Pahamu Farmer's Group Association. The eight informants were determined purposively. Also, the data collection was carried out through a focus group discussion with the Rinjung Pahamu Farmer's Group Association. The results of the study show that the local wisdom experienced by the members of the Rinjung Pahamu Farmer's Group Association was used to overcome the limited access to formal financial services. The forms of microfinance developed on the Island of Sumba could not be separated from the appreciation of the noble values (Marapu) adopted by the community, such as the philosophy of Pawandang, Hillu Kandutuku, and Rotu Padang. Furthermore, savings and loan activities carried out in the management of the Farmer's Group Association always consider the aspects of justice and survival. Based on the successful experience of the Rinjung Pahamu Farmer's Group Association, in the future, the cultural value as the basis for the microfinance development can be applied to other groups as a means to improve financial access among the poor, especially for those living in rural areas. Marapu's belief that was adopted by the people in Wangga Village still used as the basis for carrying out various activities in people's lives. Marapu's view is the belief that the government acknowledges pride, and it strengthens the community to maintain survival and balance. It practised through the Pawandang, Hillu Kandutuku, and Rotu Padang activities.
\end{abstract}

Keywords: microfinance; local wisdom; rural development; farmers groups association

\begin{abstract}
Abstrak
Penelitian ini bertujuan untuk mendeskripsikan bentuk kearifan lokal (nilai budaya) dalam keuangan mikro pedesaan. Studi ini dilakukan pada bulan Oktober sampai Desember 2018 di kelurahan Wangga, Sumba Timur. Penelitian ini menggunakan metode kualitatif untuk menangkap fenomena pengembangan keuangan mikro berbasis kearifan lokal pada masyarakat pedesaan. Para penulis menggunakan wawancara mendalam dengan delapan informan dari Gabungan Kelompok Tani Rinjung Pahamu. Kedelapan informan ditentukan secara sengaja. Pengumpulan data dilakukan melalui diskusi kelompok terarah dengan Gabungan Kelompok Tani Rinjung Pahamu. Hasil penelitian menunjukkan bahwa kearifan lokal yang yakini oleh anggota Gabungan Kelompok Tani Rinjung Pahamu digunakan untuk mengatasi keterbatasan akses layanan keuangan formal. Bentuk-bentuk keuangan mikro yang berkembang di Pulau Sumba tidak lepas dari penghayatan akan nilai-nilai luhur (Marapu) yang dianut oleh masyarakat seperti filosofi Pawandang, Hillu Kandutuku dan Rotu Padang. Lebih lanjut kegiatan simpan pinjam yang dilakukan dalam pengelolaan Gabungan Kelompok Tani selalu mempertimbangkan aspek keadilan dan keberlangsungan hidup. Berdasarkan pengalaman sukses Asosiasi Kelompok Tani Rinjung Pahamu, maka di masa depan, nilai budaya sebagai dasar untuk pengembangan keuangan mikro dapat diterapkan pada kelompok lain sebagai sarana untuk meningkatkan akses keuangan di kalangan masyarakat miskin terutama mereka yang tinggal di daerah pedesaan. Keyakinan Marapu yang diadopsi oleh masyarakat di Kelurahan Wangga masih digunakan sebagai dasar untuk melakukan berbagai kegiatan dalam kehidupan masyarakat. Keyakinan Marapu adalah kepercayaan yang diakui oleh pemerintah sebagai kebanggaan dan memperkuat masyarakat untuk mempertahankan kelangsungan hidup dan keseimbangan. Ini dipraktekkan melalui kegiatan Pawandang, Hillu Kandutuku dan Rotu Padang.
\end{abstract}

Kata kunci: keuangan mikro; kearifan lokal; pembangunan pedesaan; gabungan kelompok tani 


\section{Introduction}

The poverty problem is one of the targets of development policies in each region. Poverty is a multidimensional problem involving preferences, values, and politics. Poverty is not only a problem for developing regions, but even developed regions experience poverty. The problem is the same, but the dimensions are different. The poverty problem in developed regions is the smallest part of their community component and unlike the case with developing regions, where the problem becomes more complex because the number of poor people is almost half of the total population.

East Sumba Regency is one of 22 Regencies in the East Nusa Tenggara province that has a poverty rate above the national average. The facts show that the depth index of poverty in East Sumba Regency reached $6.96 \%$. This achievement exceeds the average depth index of poverty in the East Nusa Tenggara province at $4.69 \%$ (Central Bureau of Statistics 2016). Poverty is a prominent rural social phenomenon in East Sumba community life. The high dependence on the agriculture and livestock sector, as well as the low level of public education, contributes to poverty in East Sumba (Soegiono et al. 2019).

Since 2012, the Regional Planning and Development Agency of East Sumba Regency has carried out a SMART program that focuses on rural communities that are living below the poverty line. The program comes in the form of revolving funds used as business capital. However, in the evaluation carried out in 2017, it found that more than $50 \%$ of the funds experienced bad debts (Regional Planning and Development Agency 2017). In addition to the top-down approach that has been carried out by the government, a bottom-up approach is expected to increase the effectiveness of poverty reduction through microfinance. The bottom-up approach is built based on local wisdom growing in the community. Therefore, it is expected to be a positive energy that functions as a driving force for the success of the program. The results of the study by Soegiono et al. (2019) indicate that there was local wisdom-based microfinance in households and at the provincial level. In addition, it was revealed that microfinance was an alternative to opening up access for the poor rural residents to the financial services of formal financial institutions or banks (Kono \& Takahashi 2010, Larrú 2008, Takahashi et al. 2010, van Rooyen, Stewart, \& de Wet 2012). Moreover, the existence of microfinance institutions such as women's cooperatives provides financial services for women. It is a process to alleviate poverty in the rural area (Rustinsyah \& Dyson 2017). However, microfinance also thas a negative impact on the household (Adams \& Von Pischke 1992, Kondo et al. 2008, Ganle et al. 2015, Banerjee \& Jackson 2016, Coleman 1999, Maldonado \& Gonzólez-Vega 2008, Garikipati 2008).

Microfinance as an alternative to poverty alleviation is an instrument used in the economic empowerment of Indonesians, most of whom are based in the agricultural sector. The presence of microfinance is the basis for managing the economic potential based on trust, the norms or rules and a working network established to facilitate coordination and to strengthen coalitions within the group as a whole. The existence of microfinance as a means of socialising individuals in a shared life in society cannot be separated from its compatibility with the Indonesian culture, especially the communal culture, so microfinance is thus believed to be a means of strengthening the social relations between individuals in society. In its development, microfinance is not only used as a means to access capital, but it is also used as a means of friendship between citizens. Thus, microfinance has experienced a shift in functions from economic to social functions (Usman et al. 2004, Rustinsyah \& Dyson 2017).

Concerning the development of the economic potential on Sumba Island, the topography of the area being dominated by mountainous areas is one of the obstacles for the governments at the provincial, district and regency levels in terms of providing microfinance services. In short, it is an obstacle in terms of managing various potential resources in these areas. For example, it is challenging to lift agricultural products and household handicraft products such as woven bamboo to be marketed. As such, these areas isolated from access to public services such as health, education and the mainstream economy (Rustinsyah \& Dyson 2017).

Microfinance services have become one of the essential policy strategies in poverty reduction efforts in Sumba. Both the government and non-government institutions are directly involved in providing 
microfinance services to various groups, especially those considered to be weak economic groups such as small traders, home industries, low-level employees, labourers, and farmers and fishers. Various forms of microfinance institutions, including formal banks and non-bank institutions, non-formal institutions, government programs, and informal institutions, can be found on Sumba.

This diversity phenomenon of the poor' living conditions on the Sumba Island influences differences in access, utilisation options and the needs of low-income families for microfinance services. The agricultural sector is still the primary source of livelihood for the majority of the population in the Sumba region, although in several regions, especially near cities, trade and home industry businesses have developed. The development of agricultural and non-agricultural businesses still faces various obstacles due to the dry climate, the lack of technical mastery, weak infrastructure, and market access and unfavourable social conditions. The availability of water and the fertility of the land determine the prosperity of the community.

Microfinance development is based on a common rural development framework, and it is a form of local wisdom that consists of the valuable social relations between individuals and a network of relationships that make up the useful resources in the determination and reproduction of social positions. Forms of microfinance such as in-house social gatherings, children's education social gatherings and savings and loans that can survive in the long run generally apply the local wisdom (Soegiono et al. 2019).

East Sumba Regency has a belief called Marapu, which is an essential value within the social framework based on how to think, speak and act. It is expected to be useful for the community members to encourage them to be a superior person one day. Marapu is the basis of the local wisdom in the Sumba community concerning carrying out one's economic life in harmony with the natural and social environment. The Marapu belief in line with the principles of sustainable development (Boons \& Lüdeke-Freund 2013, Busch et al. 2016, Scholtens 2008, Starik \& Kanashiro 2013, van Marrewijk 2003) which considers the economic, ecological and social aspects (Huruta \& Kurniasari, 2018). This study is expected to contribute to identifying the forms of local wisdom that are able to encourage the development of microfinance which can be used as a guide to empowering poor rural communities (Kabeer 2005, Robinson 2002, Usman et al. 2004, Yunus 1999, Rustinsyah \& Dyson 2017), especially on Sumba Island. Based on the previous studies, this study will focus on describing the role of cultural value as the basis for microfinance development in Rinjung Pahamu Farmer's Group Association.

\section{Research Method}

This study used a qualitative approach that conducted from October until December 2018 in Wagga Village, East Sumba. A qualitative approach was carried out to identify the forms of microfinance that were developing at the community level. The form of the microfinance analysed based on the institutional aspects, both in the formal and informal contexts, as well as the participant aspect. It aimed to understand the values of society by understanding the social, economic and cultural conditions of the developing community. The fulfilment of the financial needs that are experienced by the community could not be separated from the characteristics of the local community itself. Moreover, in order to understand the depth of the researched phenomena, the authors used in-depth interviews with eight informants from the Rinjung Pahamu Farmer's Group Association. The eight informants were determined purposively. Also, the data collection was carried out through a focus group discussion with the Rinjung Pahamu Farmer's Group Association (Wangga Village - Kambera District - East Sumba Regency).

\section{Results and Discussion}

The Sumba people actualise local wisdom through economic, social and environmental behaviours. Some of the local wisdom on the island of Sumba is still being carried out, such as Pawandang, Hillu Kandutuku, and Rotu Padang. Local wisdom continues to survive amid the socio-economic changes that come from the new experiences and values that are present during today's modern life. These 
changes result in a shift in values, both positive and negative. However, this change or impact leads to something better because the culture is dynamic. The initial values are far better, so if there is an effort to maintain the existing values, then this is a very wise action. In microfinance terminology, Pawandang has mechanisms to help the members who experience economic difficulties through mutual trust in one another. Moreover, Hillu Kandutuku has the mechanism to develop businesses and to improve the economic capacity of the microfinance members. Rotu Padang supports the livestock existence of the microfinance members.

\section{Pawandang}

Pawandang is the communal values adopted by the Sumba people since ancient times. In terms of Pawandang, each of them brings their provisions from their home to the garden, so this cooperation activity does not require significant funds. The following is a Pawandang activity conducted by the members of the Rinjung Pahamu Farmer's Group Association.

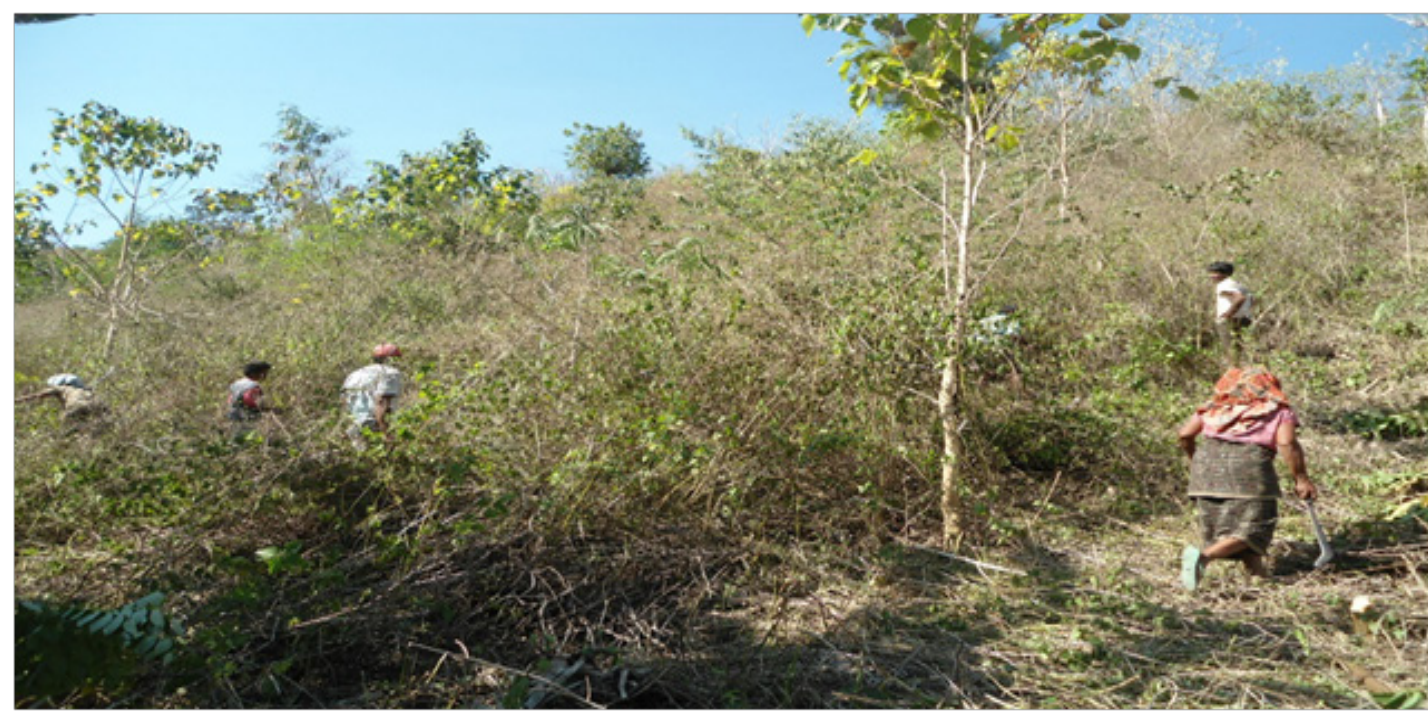

Figure 1.

Pawandang Activities at the Rinjung Pahamu Farmers Groups Association Source: Personal Documentation (2018)

These days, these local communal values increasingly maintained by the Sumba people (Huruta 2015, Huruta \& Kurniasari 2018, Huruta \& Sasongko 2016, Soegiono et al. 2019). It has become essential in developing the spirit of self-reliance and togetherness in the development process (Usman et al. 2004, Yunus 1999, Rustinsyah \& Dyson 2017). Schumacher (1979) also stated that wisdom allows us not to pursue material interests and be more inclined to pursue spiritual goals. The moral and spiritual values are like traffic signs that can reduce greed which can destroy humans themselves. It then practised in the context of the joint activities of the Rinjung Pahamu Farmer's Group Association.

\section{Hillu Kandutuku}

The ancestors of the Sumba people have long thought about alleviating poverty. This effort is made using the local wisdom (Huruta 2015, Huruta \& Kurniasari 2018, Huruta \& Sasongko 2016, Soegiono et al.2019). One of the concrete actions is to receive assistance from one's closest relatives (manu tungu pani or we tungu uhu). It is then practised in a joint group as a part of the Rinjung Pahamu Farmer's Group Association (Wangga Village - Kambera District - East Sumba Regency). The following is a form of effort from the group members, so then the cage was not empty (Hillu Kandutuku).

If the assistance developed adequately, then it could be returned to the aid provider. The calculation was that they had to return half of the number of piglets or chicks. The rest, which was raised by the farmer, might belong to the farmer entirely. If they wanted to have the parents of the pigs or chickens forever, then they were allowed to return more than half of the number of piglets or chicks. 
Concerning education problems, livestock such as cattle, buffaloes, horses, goats or pigs would continue to be maintained until their children had finished their studies in high school and then the livestock were sold to register their children in college. It considered being a form of local wisdombased saving at the household level.

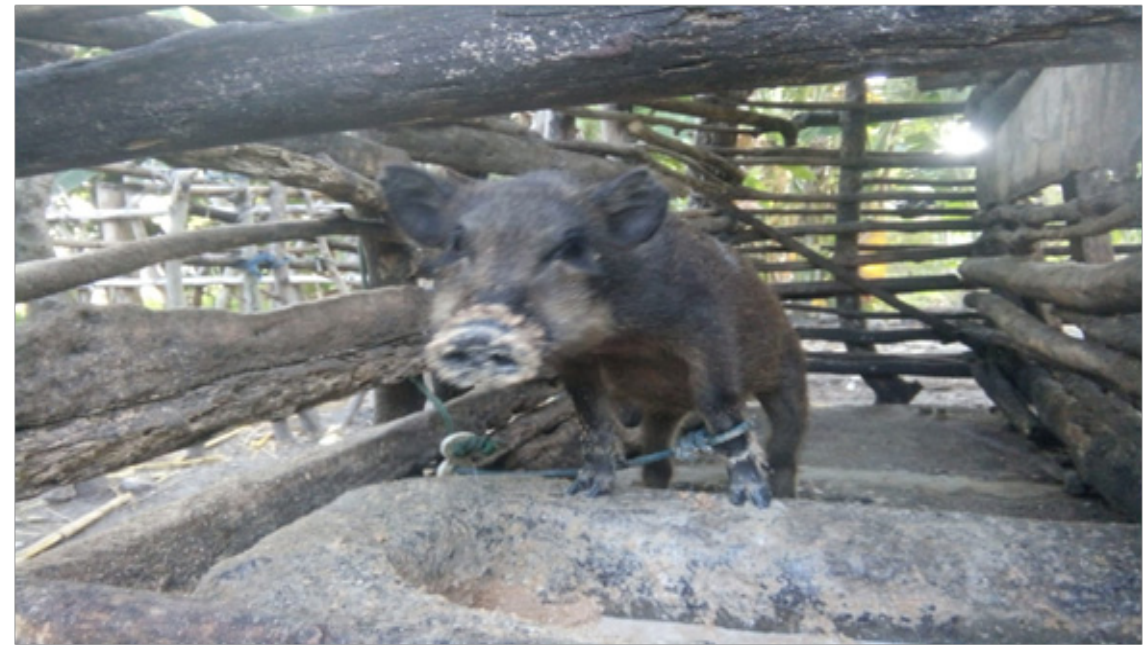

Figure 2.

Cages and Pigs of the Farmers Groups Association Members Source: Personal Documentation (2018)

\section{Rotu Padang}

Rotu implies that there is an effort to preserve the existence of livestock by fighting the greedy feeling to use livestock as an object to meet one's economic and social needs. Rotu is applied when there is an agreement in the community, making the Rotu very local (Huruta 2015, Soegiono et al. 2019). It means that livestock should be allowed to develop according to the agreed-upon time, so then the livestock population is maintained and increased in terms of quantity. It is the starting point of sustainability (Boons \& Lüdeke-Freund 2013, Busch et al. 2016, Huruta \& Sasongko 2016, Scholtens 2008, Soegiono et al. 2019, Starik \& Kanashiro 2013, van Marrewijk 2003). The following is a form of Rotu Padang activity carried out by the members of the Rinjung Pahamu Farmer's Group Association.

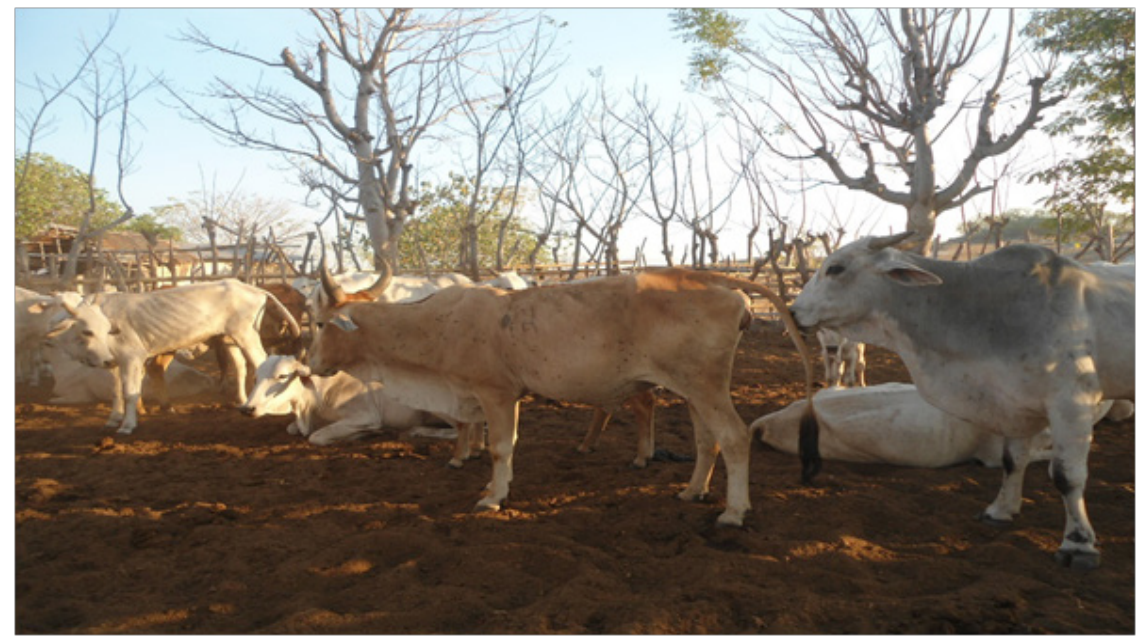

Figure 3.

Rotu Padang System Conducted by the Rinjung Pahamu Farmers Groups Association Members Source: Personal Documentation (2018)

In its implementation, if someone had much livestock, then the livestock should not be used for a common purpose such as a death ceremony. The values have begun to shift where horses, cows or buffaloes (that were still in the mother's womb) had been sold, corn (that was not ready to be 
harvested) already harvested for consumption and small chickens had also been cut or sold, and so it was with the other livestock. It was a form of disobedience by the Sumba people. Some suggestions must be considered, namely pa mbotu ta na lima, pa mbotu ya na eti (Soegiono et al. 2019). It means that any assets should not be used carelessly. There was adherence to protecting the assets such as livestock, except if they were unproductive or if their livestock their experienced new physical defects, after which they were allowed for sale or consumption.

\section{Microfinance activities at Rinjung Pahamu Farmer's Group Association}

The Marapu belief was the basis for carrying out activities in the Rinjung Pahamu Farmer's Group Association. The regulation and continuity of savings and loan activities, the sale of the results of livestock cultivation and the distribution of business results used Marapu as a basis for compiling the policies and rules used. Savings and loans as a form or as a component of social capital had long existed in the lives of Sumba people, most of whom were based in the agricultural sector. The system was known as the basis of savings and loan activities in social capital, including trust and networking (Nugroho 2008). The existence a Pawandang norm was guideline for the participants or members involved in it, as well as it allows for the existence of a network established to facilitate coordination and to strengthen the coalitions within the group. The sustainability of savings and loan activities as a means of socialising individuals in a shared life in the community could not be separated from their compatibility with the Sumba culture, especially the communal culture. The savings and loan activities were believed to be a means of strengthening the social relations between individuals in society (Nugroho 2008, Usman et al. 2004, Yunus 1999). Togetherness as a form of communal life is the main characteristic of this savings and loan activity. Group life patterns originating from the kinship culture facilitated the various activities carried out from, by and for the group interests. In the groups, there were social sanctions as well as social concerns for the members.

Savings and loan activities were also based on the philosophy of Hillu Kandutuku (the cage should not be empty), and Rotu Padang completed these activities (Soegiono et al. 2019). In terms of the financial terminology and context of the Rinjung Pahamu, the Farmer's Group Association, savings, and loan activities were a form of investment activity and business credit for its members (Augsburg 2009, Janda \& Svárovská 2010). It indicated by the existence of funds from the Farmer's Group Association in livestock sales as funds for the development of other activities. The savings and loan activities by utilising joint capital through livestock sales showed the application of the local wisdom of Rotu Padang and tungu pani or tungu uhu. Therefore, the Rotu Padang system was an attempt to reserve pastures from a clan that implied environmental preservation or reservations (Boons \& Lüdeke-Freund 2013, Brown et al. 1987, Huruta 2015, Huruta \& Kurniasari 2018, Huruta \& Sasongko 2016, Soegiono et al. 2019, Starik \& Kanashiro 2013, van Marrewijk 2003).

\section{Conclusion}

The village economy is based on local centres because it promotes cultural values. In this case, the culture values (local wisdom) applied in the microfinance development of the Rinjung Pahamu Farmer's Group. Based on the successful experience of the Rinjung Pahamu Farmer's Group Association, in the future, the local wisdom-based microfinance development model with a bottomup approach can be applied to other groups as a means of increasing financial access among the poor, especially for those living in rural areas. The Marapu belief adopted by the community in the Wangga Village still used as a basis for carrying out various activities in people's lives. The Marapu belief is the trust recognised by the government to be a source of pride, and it strengthens the community by maintaining survival and balance. It practised through the Pawandang, Hillu Kandutuku, and Rotu Padang activities.

\section{References}

Adams DW \& Von Pischke JD (1992) Microenterprise credit programs: Déja vu. World Development 20 (10):1463-1470. DOI: 10.1016/0305-750x(92)90066-5. 
Augsburg B (2009) The impact of a dairy intervention in rural India: Evidence from realised outcomes and expected returns to investment. Journal of Development Effectiveness 1 (2):147-170. DOI: $10.1080 / 19439340902903211$.

Banerjee SB \& Jackson L (2016) Microfinance and the business of poverty reduction: Critical perspectives from rural Bangladesh. Human Relations 70 (1):63-91. DOI: 10.1177/0018726716640865.

Boons FAA, \& Lüdeke-Freund F (2013) Business models for sustainable innovation: State-of-the-art and steps towards a research agenda. Journal of Cleaner Production 45:9-19. DOI: 10.1016/j. jclepro.2012.07.007.

Brown BJ, Hanson ME, Liverman DM, \& Merideth Jr RW (1987) Global sustainability: Toward definition. Environmental Management 11 (6):713-719. DOI: 10.1007/bf01867238.

Busch T, Bauer R, \& Orlitzky M (2016) Sustainable development and financial markets: Old paths and new avenues. Business \& Society 55 (3):303-329. DOI: 10.1177/0007650315570701.

Central Bureau of Statistics (2016) Provinsi Nusa Tenggara Timur Dalam Angka 2016. Kupang.

Coleman BE (1999) The impact of group lending in Northeast Thailand. Journal of Development Economics 60 (1):105-141. DOI: 10.1016/s0304-3878(99)00038-3.

Ganle JK, Afriyie K, \& Segbefia AY (2015) Microcredit: Empowerment and disempowerment of rural women in Ghana. World Development 66:335-345. DOI: 10.1016/j.worlddev.2014.08.027.

Garikipati S (2008) The impact of lending to women on household vulnerability and women's empowerment: Evidence from India. World Development 36 (12):2620-2642. DOI: 10.1016/j.worlddev.2007.11.008.

Huruta AD (2015) Membangun Dengan Pengalaman di Tengah Perubahan. Salatiga: Satya Wacana University Press.

Huruta AD \& Kurniasari MD (2018) Environmental management within the indigenous perspective. Masyarakat, Kebudayaan dan Politik 31 (3):270-277. DOI: 10.20473/mkp.v31i32018.270277.

Huruta AD \& Sasongko G (2016) Uang dan ruang yang berkelanjutan dalam pembentukan Badan Usaha Milik Desa (BUMDes). Masyarakat, Kebudayaan dan Politik 29 (4):212-222. https:// e-journal.unair.ac.id/MKP/article/view/2615.

Janda K \& Svárovská B (2010) Investing into microfinance. Journal of Business Economics and Management 11 (3):483-510. DOI: 10.3846/jbem.2010.24.

Kabeer N (2005) Is microfinance a "Magic Bullet” for Women's Empowerment? Analysis of findings from South Asia. Economic and Political Weekly 40 (44/45):4709-4718. https://www. microfinancegateway.org/sites/default/files/mfg-en-paper-is-microfinance-a-magic-bulletfor-womens-empowerment-analysis-of-findings-from-south-asia-oct-2005_0.pdf.

Kondo T, Orbeta AJr, Dingcong C, \& Infantado C (2008) Impact of microfinance on rural households in the Philippines (PIDS Discussion Paper Series No. 2008-05). https://dirp3.pids.gov.ph/ris/ dps/pidsdps0805.pdf.

Kono H \& Takahashi K (2010) Microfinance revolution: Its effects, innovations and challenges. The Developing Economies 28 (1):15-73. DOI: 10.1111/j.1746-1049.2010.00098.x.

Larrú JM (2008) Random impact evaluations and microcredits. Revista de Economia Mundial 19:3362. http://www.sem-wes.org/es/node/241.

Maldonado JH \& González-Vega C (2008) Impact of microfinance on schooling: Evidence from poor rural households in Bolivia. World Development 36 (11):2440-2455. DOI: 10.1016/j. worlddev.2008.04.004.

Nugroho AE (2008) A critical review of the link between social capital and microfinance in Indonesia. Jurnal Ekonomi dan Bisnis Indonesia 23 (2):124-142. https://jurnal.ugm.ac.id/jieb/article/ view/6344. 
Regional Planning and Development Agency (2017) Laporan Akhir Evaluasi Program SMART. Sumba Timur.

Robinson MS (2002) The Microfinance Revolution: Lessons from Indonesia. http://hdl.handle. net/10986/14254.

Rustinsyah \& Dyson L (2017) Could the existence of microfinance institution for alleviation poverty in rural area? A case study in women's cooperative in Magersari Village, Plumpang Sub-district, East Java, Indonesia. Proceedings of the 1st International Conference Postgraduate School Universitas Airlangga: Implementation of Climate Change Agreement to Meet Sustainable Development Goals (ICPSUAS 2017) 98: 138-144. DOI: 10.2991/icpsuas-17.2018.31.

Scholtens B (2008) Note on the interaction between corporate social responsibility and financial performance. Ecological Economic 6 (1-2):46-55. DOI: 10.1016/j.ecolecon.2008.01.024.

Schumacher EF (1979) Kecil Itu Indah. Jakarta: LP3ES.

Soegiono L, Atahau ADR, Harijono, \& Huruta AD (2019) Local wisdom in rural microfinance: A descriptive study on villagers of East Sumba. Entrepreneurship and Sustainability Issues 6 (3):1485-1496. DOI: 10.9770/jesi.2019.6.3(30).

Starik M \& Kanashiro P (2013) Toward a theory of sustainability management: Uncovering and integrating the nearly obvious. Organization and Environment 26 (1):7-30.

Takahashi K, Higashikata T, \& Tsukada K (2010) The short-term poverty impact of small-scale, collateral-free microcredit in Indonesia: A matching estimator approach. The Developing Economies 48 (1):128-155. DOI: 10.1111/j.1746-1049.2010.00101.x.

Usman S, Suharyo WI, Soelaksono B, Toyamah N, Mawardi MS, \& Akhmadi (2004) Keuangan Mikro untuk Masyarakat Miskin: Pengalaman Nusa Tenggara Timur. http://www.smeru. or.id/sites/default/files/publication/microfinance_ntt_ind.pdf.

Van Marrewijk M (2003)Concepts and definitions of CSR and corporate sustainability: Between agency and communion. Journal of Business Ethics 44 (2):95-105. DOI: 10.1023/a:1023331212247.

Van Rooyen C, Stewart R, \& de Wet T (2012) The impact of microfinance in Sub-Saharan Africa: A systematic review of the evidence. World Development 40(11):2249-2262. DOI: $10.1016 / \mathrm{j}$. worlddev.2012.03.012

Yunus M (1999) Banker to the Poor. United States: PublicAffairs. 